\title{
Using Audio Visual Materials for Civil Engineering Students to Gain Field Experience in Schools: Stone Wall Example
}

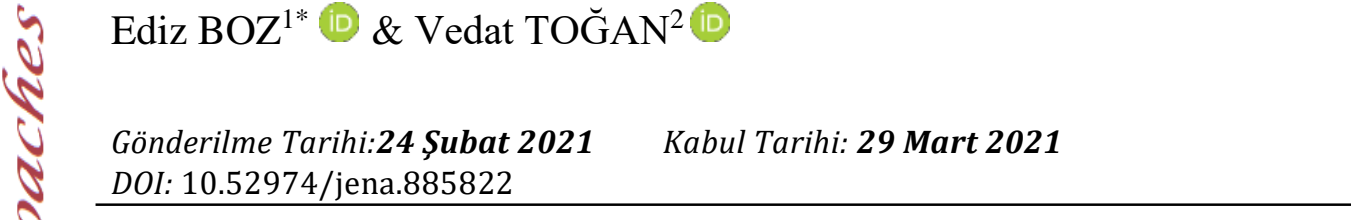 \\ $\ddot{O} z:$ \\ Çalıştıkları birçok görevde büyük sorumluluklar alan inşaat mühendisleri, böyle önemli \\ bir mesleğe sahip olmadan önce belirli bir eğitimden geçmektedirler. Aldıkları bu ĕgitim \\ ile birlikte meslek hayatlarında karşı karşlya kalacakları sorumlulukları yerine \\ getirmeleri beklenmektedir. Bu yüzden, inşaat mühendislerinin toplum için yapttkları \\ çalışmalar kadar aldlkları eğitim de çok önemlidir. İnşaat mühendislerine verilen \\ eğitimin teorik ăğrllklı olması, bütün üniversitelerde gerekli laboratuvar \\ ekipmanlarının bulunamamasl, öğrencilerin istedikleri kalitede veya pozisyonda staj \\ yeri bulamamast gibi sebepler inşaat mühendisliği eğitiminde teorik ĕgitim ile \\ uygulamanın bağdaştırılabilmesini zorlaştırmaktadır. Yapılan inşsaat projelerinin \\ büyüklü̆̈̈̈ ve karmaşıklığı, yeni teori, malzeme ve ihtiyaçların ortaya çıkmasl, \\ firmaların çalışı̆ı̆ iş̧in yapım aşamalarına ve kullanılan teknolojiye hakim inşaat \\ mühendisi arayışını arttırmışıtır. Firmaların bu taleplerini karşılamak, uygulamayı, \\ kullanilan teknolojiyi, işin yapım aşamalarını vb. konularda yetişmiş kişilerle mümkün \\ olacaktır. Bu sebeple inşaat mühendisliği eğitiminde uygulama ile teorik eğitimin \\ ilişsilendirilmesi oldukça önemli bir problemdir. Bu çalışmada, öğrencilerin \\ üniversitelerde aldıkları teorik bilgilerle uygulamayı ilişkilendirmede yaşadıkları \\ problemlere karşı video kullanımının üretebildiği çözümler araştırılmıştır. Bu amaçla, \\ yapılan işler şantiyelerdeki orijinal haliyle görsel kayıt altına alınmış ve belirli bir \\ senaryo hazırlanarak yapılan işler seslendirilmişstir. Hazırlanan görsel-işitsel \\ materyaller üç üniversitede toplam 261 ögrenciye izlettirilmiş ve peşi sıra yapılan anket \\ ile bu çalışmadan alınan verim tespit edilmiştir. Çalışma sonucunda, görsel işitsel \\ materyal kullanımının ögrencilerin yapım işi uygulamalarındaki eksikliklerinin \\ giderilmesine katkı sağlayabildiği görülmüşı̈̈r. \\ Anahtar Kelimeler: Mühendislik eğitimi, görsel-işitsel materyal kullanımı, eğitim \\ materyali, yap teknolojisi.

\begin{abstract}
:
Civil engineers taking great responsibilities in many tasks they work, get educated in university before they have such an important profession. With this education, they are expected to fulfill the responsibilities they will face in their professional life. Therefore, the education received by civil engineers is as important as their work for society. Students from schools with more theoretical education have difficulties on understanding of practical applications in the field. To overcome these understanding challenges, students have been supplemented with audio-visual materials that contain
\end{abstract}

\footnotetext{
${ }^{1}$ Bayburt Üniversitesi, Türkiye. Orcid ID: 0000-0002-4824-4739

${ }^{2}$ Karadeniz Teknik Üniversitesi, Türkiye. Orcid ID: 0000-0001-8734-6300

*Sorumlu Yazar (Corresponding Author): edizboz@ bayburt.edu.tr
} 
practical knowledge based on theoretical background. For this purpose, the process of the construction work was visually recorded in original form from construction site and a specific scenario was prepared and performed. Prepared audio-visual material was then presented to a total of 261 students and the efficiency of the materials was determined. As a result of this study, it was seen that the use of audio-visual material contributed to the elimination of the deficiencies of the students in the construction work applications.

Keywords: Engineering education, use of audio-video, education material, construction technology.

\section{INTRODUCTION}

Developing construction materials and techniques brings challenges of finding jobs to newly graduated civil engineers due to the lack of applications in their time at engineering schools (Chakrabarti 2016; Vítková et al., 2013). With traditional civil engineering education, civil engineering students learn more of the theory rather than applications because not many schools have decent laboratories (labs) in every subfield of civil engineering (Hoyer et al., 2004). Although students from schools with insufficient labs try to find internships that can fulfil their lacking of applications, not many of them are lucky enough to find good internships (Mills \& Treagust 2003; Hoyer et al., 2004; Oguz et al., 2009). Therefore, bringing Audio-Visual Materials (AVM) to classroom environment would increase the practical knowledge of students about real life engineering problems and their solutions.

AVM have been proven to increase the quality of the engineering education (Stefanova, 2014). AVM allow students to interact with more problems and experiments than traditional labs because it is not possible to bring every single real-life problem to classroom environment. It is also important to note that the establishing labs for every engineering problem would require a lot of physical space and cost much more than AVM. AVM also allows students to pause and zoom-in the video when they need to ask questions to clarify what they have missed or wanted to learn more details by touching different senses of the students. However, written materials do not allow students to visualize the engineering problem (Bétrancourt and Benetos, 2018; Brecht \& Ogilby, 2008; Craig \& Friehs, 2013; Kay, 2012; Lai et al., 2016; Martin, 2016; Prince and Felder, 2006; Seferoğlu, 2006; Wang et al., 2016; Wiggins and McTighe, 2008; Zhang et al., 2006).

There are lots of advertisement videos about materials, jobs and construction companies which give little bit practical and theoretical information about the real-life problems. However, most of these videos contain problems such as poor preparation, excessive information, not providing the necessary information or removing important points. A certain minority of such videos has been shown to be useful for teaching due to misleading content and poor quality. (Ajumobi et al., 2016; Belkina et al., 2015; Fischer et al., 2013; Raikos \& Waidyasekara 2014; Rittberg et al., 2016; Yaylac1 et al., 2014). Therefore, the aim of this study is to present audio-visual materials which bring together the theoretical and practical knowledge of civil engineering in a more scientific way. To this end, construction process of a stone retaining wall, which is widely used in Turkey has been video-recorded. Moreover, the recorded video has been post-processed to add voiceover of the construction process, materials being used, construction techniques and their theoretical background. 


\section{METHOD}

The steps in the figure 1 were applied to prepare the AVM of the stone retaining walls and to demonstrate the usability of these AVM.

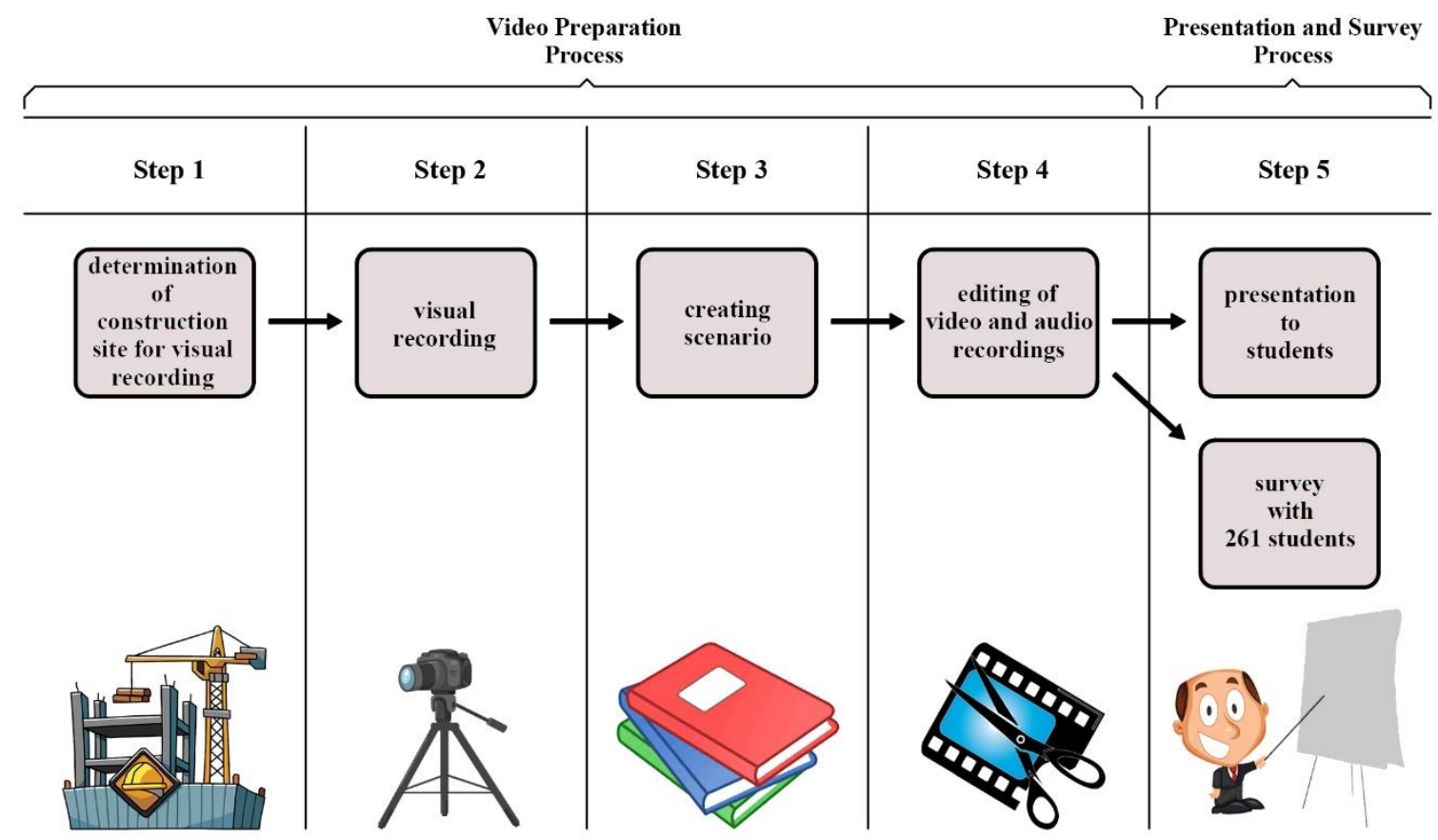

Figure 1: Steps for prepare the AVM

\section{Determination of Construction Site for Visual Recording}

The work started by determining the suitable construction sites in which stone retaining walls were built before taking visual records. Stone wall works are usually found in transportation works. Regional Directorate of Highways is responsible for transportation in Turkey. Six stone wall construction sites were identified according to the information obtained from the 10th Regional Directorate of Highways. Be very careful while determination of construction site because any situation that hinder the video recording will extend the working time. Any construction phase that cannot be recorded visually should be waited to be repeated on another wall. If the visual records are made on different walls, inconsistencies will occur in the material prepared. To avoid the mentioned problems, determined construction sites were evaluated by considering several criteria. This criteria given in table 1. 
Table 1. Criteria for determining construction site

\begin{tabular}{ll}
\hline $\begin{array}{l}\text { Criteria Before } \\
\text { Starting Video }\end{array}$ & $\begin{array}{l}\text { The excavation of the building must have not started } \\
\text { The excavation of the building must be continuing } \\
\text { Accommodation should be close to the construction site in order not to miss any process } \\
\text { of production }\end{array}$ \\
\hline $\begin{array}{l}\text { Criteria During } \\
\text { Video Shooting }\end{array}$ & $\begin{array}{l}\text { It should be possible to go to the necessary places at any time for the construction process } \\
\text { to be shoot video from the front, back and side } \\
\text { In order to be able to show the fine details to the student such as how the stones are } \\
\text { straightened and lined, how the mortar is formed, how the level is given, how the barbs } \\
\text { are put, etc., both the construction site should be available and this situation should not } \\
\text { cause a problem for the site team. } \\
\text { Finding a suitable ground for the tripod in the places where the camera will be fixed in } \\
\text { order to stabilize the camera }\end{array}$ \\
\hline Plan B & $\begin{array}{l}\text { It is necessary to have retaining walls that have not yet started to be built on the } \\
\text { construction site for use in case of any undesirable malfunction that may occur in the } \\
\text { shooting. }\end{array}$ \\
\hline
\end{tabular}

The determined construction sites were evaluated by considering several criteria such as whether construction has yet started or the excavation works are continuing, access to the necessary places, accommodation is close to construction site, finding suitable ground for tripods in order to make visual recording healthy and high quality. As a result of the evaluation, it was decided that the most suitable conditions for visual recording were in the road construction site in Aydintepe district of Bayburt.

\section{Visual Recording}

With the recommendations of the site manager and the technical team at the selected site, the most suitable for visual recording were determined from the manufacturing points. The images to be recorded have been created a visual base for what will be explained in the scenario. Therefore, the applications made by the construction workers at the construction site, the solutions they find related to the problems they face, the materials, machines and equipment used in the application are recorded visually in their original form.

Stone wall construction consists of eight main parts. These main parts are as follows project phase, excavation works, foundation, placement of slope boards, correcting the shapes of the stones and arranging them, making the mortar and its use in stone walls, placing barbakans and screed and joint construction. Photos of each process are shown figure 2. 


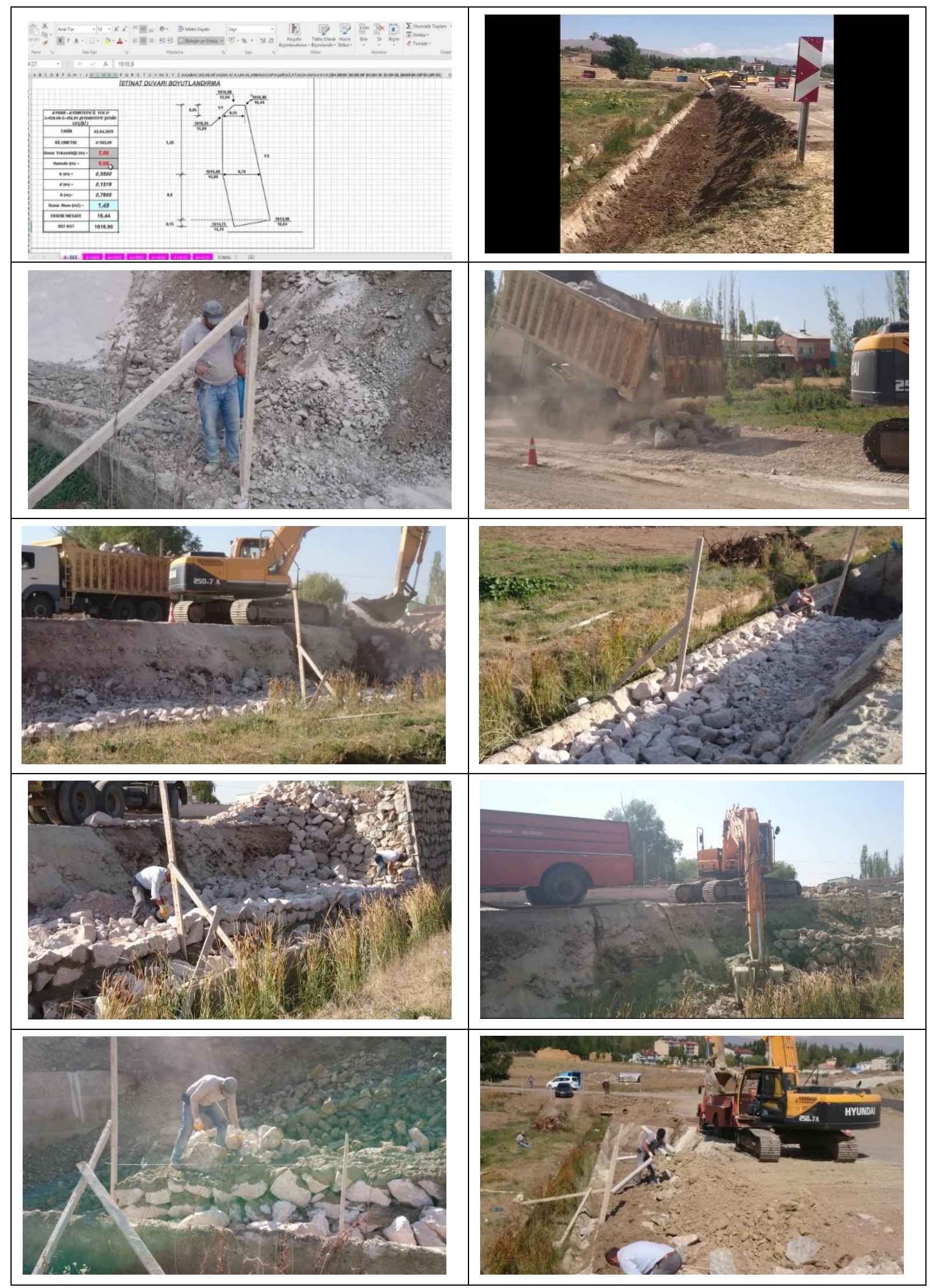




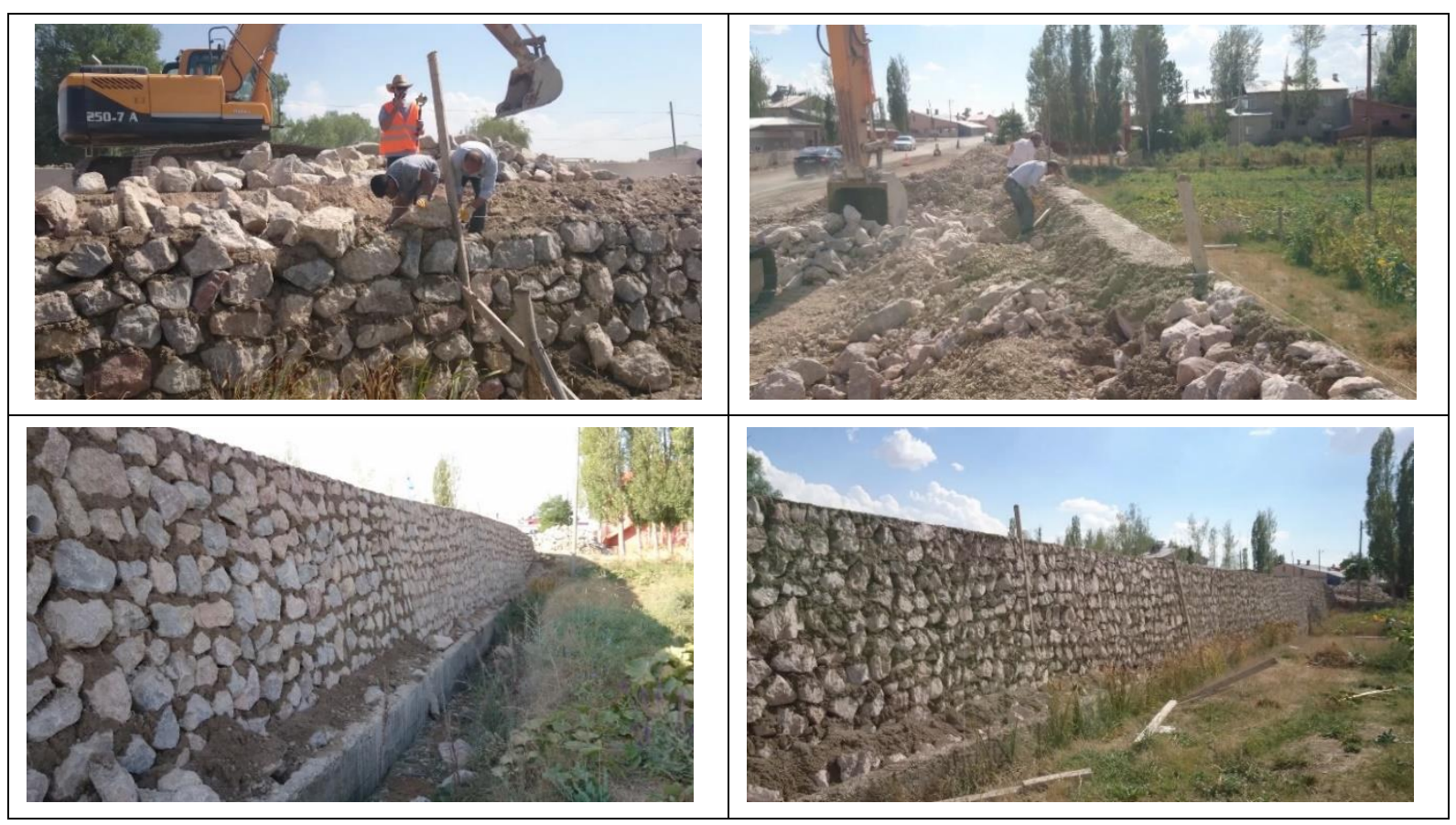

Figure 2: Photos showing project and construction sites

\section{Creating Scenario}

After the stone wall productions have been recorded visually, a scenario must be created in order to make audio recordings. During the creation of the scenario, there are things to pay more attention such that the order, in which the productions are made, how it is done, used technology and materials in a construction site. To get the correct purpose of the audio-video across to students, help is taken from the technical specifications used in Turkey (DSİ, 2014; KGM, 2013), civil engineers with many years of experience and supervisors from the stone wall construction site, textbooks and notes (Avc1oğlu, 2011; Önal, 2018). With the help from different resources, a scenario was prepared regarding the construction of the stone walls.

In the introduction part of the scenario, it is explained in which situations stone walls are preferred. After the introduction, process such as ground studies, choosing the wall type, incoming loads and project planning are briefly mentioned. Then, information such as what the symbols in the project mean and which elements belong to the dimensions shown are given. After the project information was given, the description of the construction of the stone wall was started in the scenario. At this process, it was explained how the properties of the materials were determined using technical specifications. After giving information about the material, the role of work machines and topographical engineers in excavation operations was explained. After the excavation is completed, the preparation of the construction templates, the materials used (plumb, meter, nail, hammer, etc.) and the purpose of the construction templates are written in the script. After the route of the stone wall is adjusted, the foundation construction is started. After the foundation is completed, the visuals show the workers arranging the stones. Parallel to these visuals, how the workers should arrange the stones, what they should pay attention to, how the shapes of the stones were brought to the desired shape and which tools were used were written in the scenario. In the visuals, the stone walls are lined up as a row of stone and a row of mortar. At this process, it is planned to explain what the mortar is and what properties it should have. Then, these concepts were written in the scenario in order to explain 
the concepts of formation of mortar (water, sand, cement) and dose (cement amount in $1 \mathrm{~m} 3$ mortar). After explaining the mortar, the reason why the barbakans were placed on the stone wall was written in the script. Finally, the purpose of the infinitive and joint was written in the script and the written text base was created for the visuals. Written texts created in reinforced concrete and stone wall scenarios were associated with visual recordings and voiced.

\section{Editing of Video and Audio Recordings}

Visual recordings taken from the construction site and audio recordings prepared were edited before presenting to the students. During this editing process voice recordings were taken as the base. The visual recordings are shortened, extended, accelerated or interrupted according to how many seconds or how many minutes a topic is mentioned in the scenario. In the video montage, a computer program was used in which the audio and video can be edited in high quality separately, adding and subtracting, and writing and figures could be added in the video.

The sound recordings of the script lasted 10 minutes in total. When the 10-minute audio-visual materials prepared were watched by the experimental group students, the time was found to be long. For this reason, some details in the scenario have been removed and the time has been tried to be shortened. The sound recording has been reduced to 5 minutes. Audio-visual materials, which were re-assembled according to the shortened sound recordings, were made ready to be presented to the students. The photo about the editing of the video is given in figure 3.

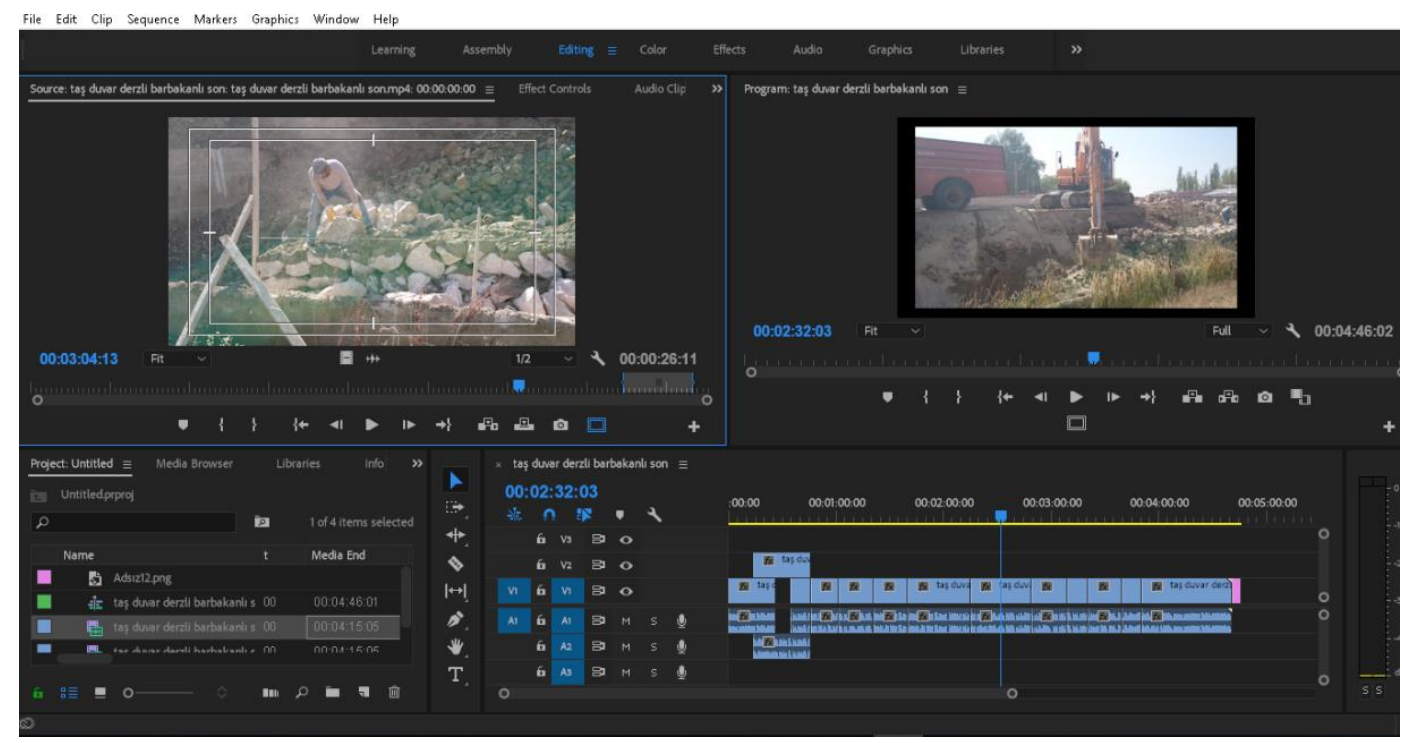

Figure 3: A photo showing editing of video

\section{Presentation to Students and Survey with 261 Students}

9-question survey was conducted in order to determine the usability and effectiveness of the prepared video in the field of production technology. Top eight questions were asked in Likert type. In this scale type, the student decides one of the 5 degrees "5- strongly agree", "4- agree", "3- undecided", "2- disagree", "1- absolutely disagree". In this way, students' level of agreement on questions can be well justified. The last question was not asked in Likert Type. It was about time of prepared AVM and students answered it in the form of appropriate, short or long. Prepared audio-visual material was presented to 261 students from three universities in 
Turkey (121 from Black Sea Technical University, 92 from Gümüshane University, 48 from Bayburt University) during the spring semester of the 2018-2019 academic year. The screenings in each university were held on different dates and a face-to-face survey was conducted with the experimental student group after the screening. Experimental groups were randomly selected among the senior civil engineering students who completed their internship and had a semester to graduate. Because this group of students can justify better due to the fact that they were about to graduate with the current education system and material, whether the prepared material would contribute (overcome the deficiencies) to education, the survey was conducted with senior civil engineering students. Single video was presented to students and the duration of the video is 5 minutes. The photo taken during the survey is given in figure 4.

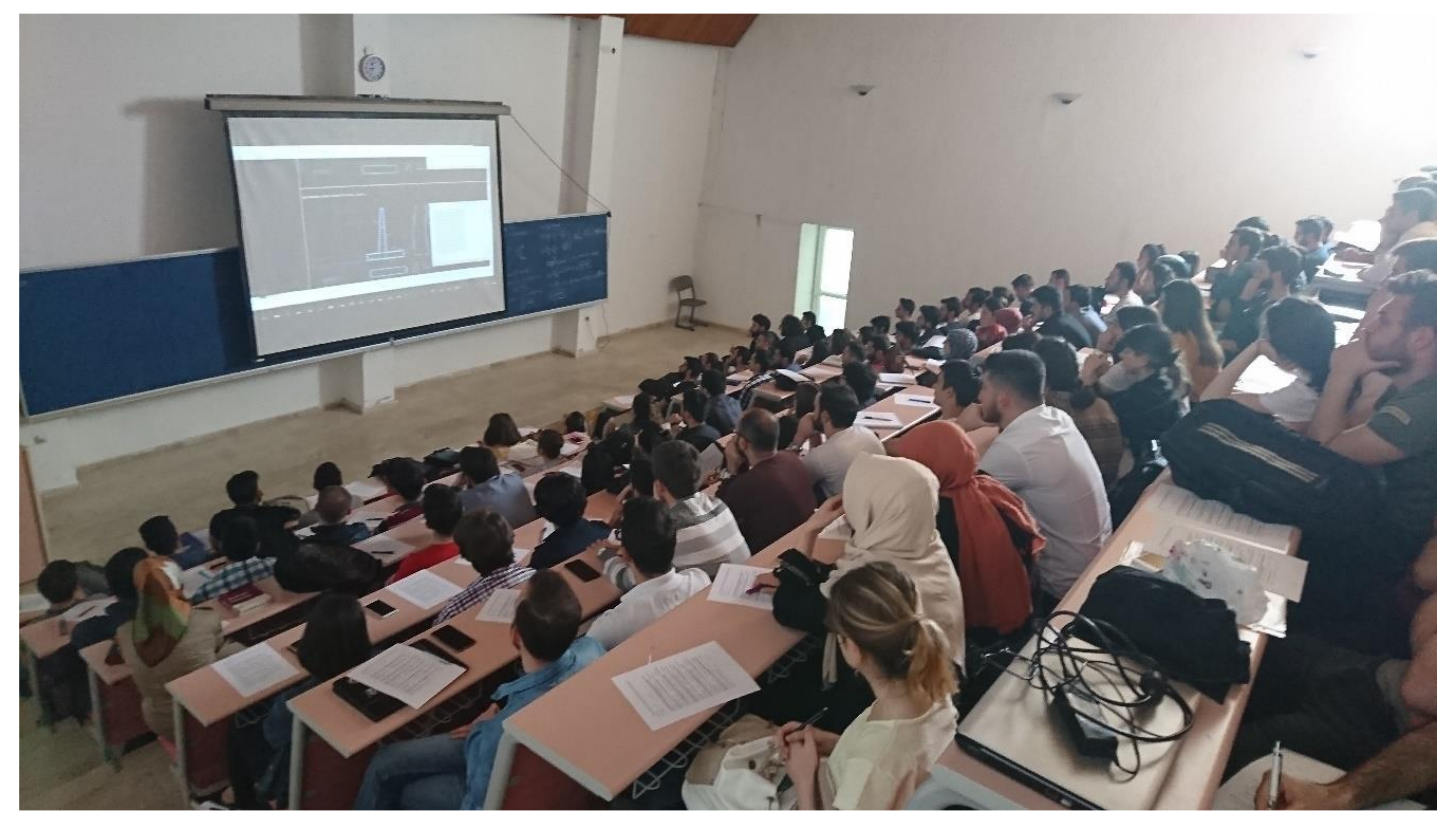

Figure 4: A photo taken during survey

After the survey was applied, the data were transferred to Excel ${ }^{\circledR}$ program and it was determined by filtering method how many people gave which answer to which question. Cronbach's alpha analysis was applied to determine the reliability and validity of the Likert scale used in the questionnaire. Cronbach's alpha coefficient (R2) takes values in the range of 0 to 1 , meaning that the results are more reliable as the alpha coefficient converges to 1 . The Cronbach alpha coefficient of the questionnaire was determined to be 0.7124 . When the intervals given in Table 2 (Y1ld1z \& Uzunsakal, 2018) are considered for reliability, it is seen that the survey study is quite reliable $\left(0.60<\mathrm{R}_{2}\right.$ coefficient $\left.<0.80\right)$.

Table 2. Cronbach Alpha Coefficient

\begin{tabular}{ll}
\hline $0<\mathrm{R}_{2}<0.4$ & Not Reliable \\
$0.4<\mathrm{R}_{2}<0.6$ & Low Reliable \\
$0.6<\mathrm{R}_{2}<0.8$ & Quite Reliable \\
$0.8<\mathrm{R}_{2}<1$ & High Reliable \\
\hline
\end{tabular}




\section{RESULTS, DISCUSSION}

Descriptive statistical analysis of the answers, given to the survey questions, are presented in Table 3. In the top eight questions, students answered 5-point Likert scale (LT-5 strongly agree, LT-4 agree, LT-3 undecided, LT-2 disagree, LT-1 absolutely disagree).

Table 3. Top Eight Questions and Students Answer

1) Do you feel the need to learn how the various structures are built and the materials and technology the workers use, along with the education you get at school?

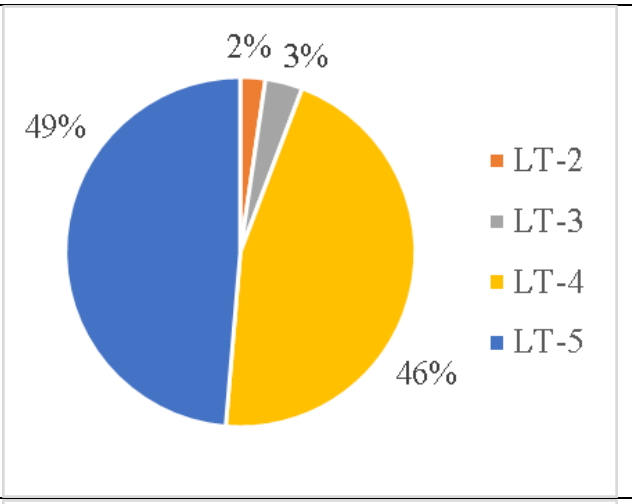

2) Do you think the videos you watch will increase your knowledge of the application?

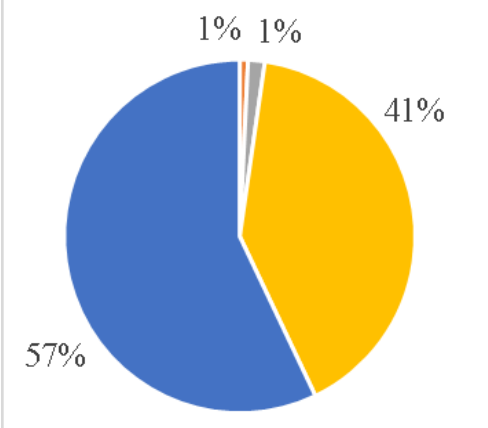

3) Do you think that learning how construction applications are made and which materials and technologies are used will increase your chances of finding a job?

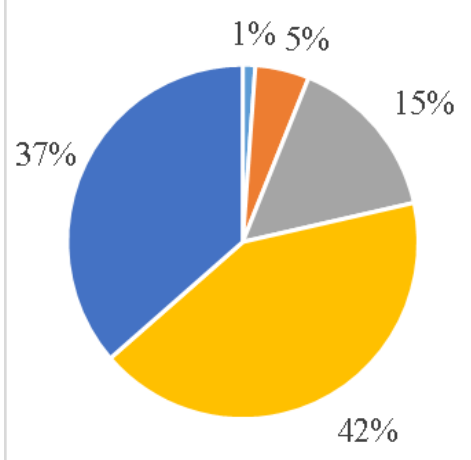

4) After watching these videos, do you think that your ability to learn the theoretical knowledge about reinforced concrete and stone retaining walls increases?

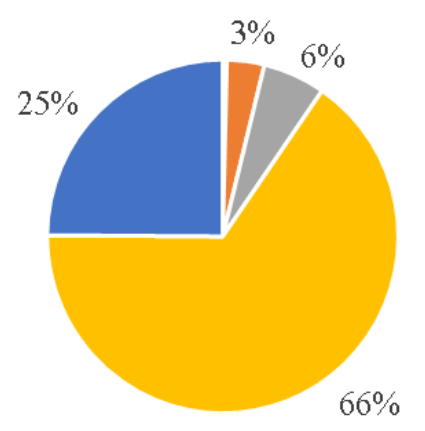


5) Do you think that the information learned provides persistence thanks to these videos?

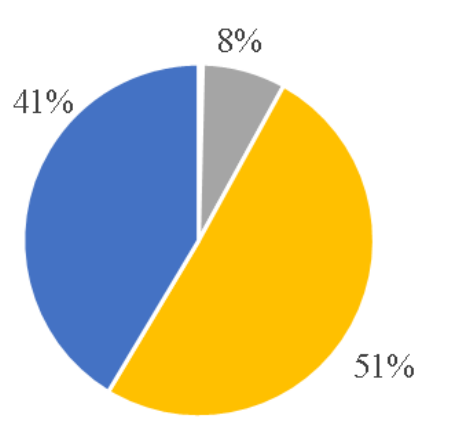

6) Do you recommend that other applications in the construction sector to be demonstrated using audio-visual materials in this way?

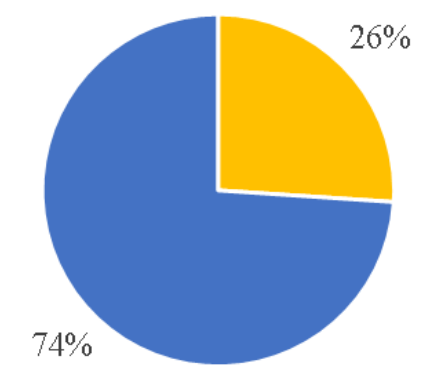

7) Did these videos help you learn how to make reinforced concrete and stone retaining walls?

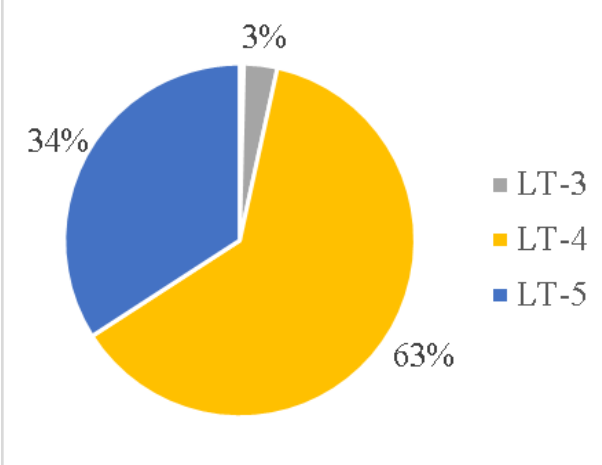

8) Did these videos help you learn about the materials and technology used by workers in reinforced concrete and stone retaining wall construction?

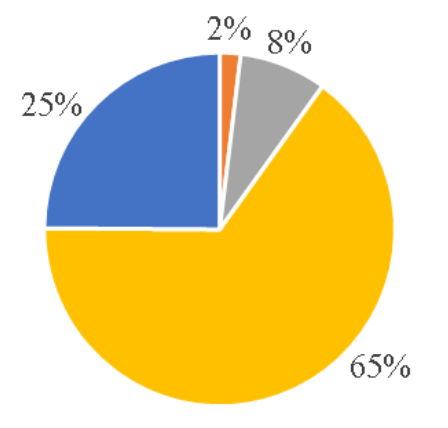

$95 \%$ of the students respond positively to the first question in the survey shows that they feel the need to learn how to make the structure together with the materials and technology used in the construction works. In the literature, it is stated that the traditional education system has deficiencies in this direction (Boz et al., 2017; Lu \& Xue, 2017). None of the students answered "Absolutely No" to the first question in the questionnaire is another finding that pointing to the related deficiency. 
Almost all of the students responded positively to the second question in the survey show that they can substantially complete the application knowledge they feel is lacking through audiovisual materials. This finding is due to the fact that today's students are the " $Z$ " generation and students' desire to learn with audio-visual materials consistent with the situation, as stated in the literature (Vergara et al., 2017; Y1ldırım \& Özmen,2011). Therefore, students can see the activities on the construction site without going to the site thanks to the correctly prepared audio-visual materials. For various reasons, students may experience disruptions in laboratory and internship studies during their education and they can not be able to see the application adequately. It is seen that audio-visual materials can cover the deficiencies in this subject at a lower cost.

The $79 \%$ positive response to the third question in the survey shows that students establish a relationship between learning practice and finding a job, and also this finding shows that students are aware of the construction companies expectations stated in the literature (Özkan, 2011). Construction companies expect to have knowledge about manufacturing and construction site applications from civil engineers. The use of audio-visual materials to show the productions to the students with real images in the construction area makes them think that the students will graduate more confidently and can meet the expectations of the companies more easily.

In the literature, it is said that civil engineering students have difficulty in visualizing information especially in their mechanic courses and therefore they are not successful in related courses. It is also recommended in the literature to give examples of real-life visuals as solutions to this situation (Bikçe et al., 2011; Lai et al., 2016; Stefanova, 2014). 91\% of the students responded positively to the fourth question in the survey is consistent with the literature. It is thought that the theoretical knowledge will be more easily understood after the applications are shown to the students by using audio-visual materials.

Seferoglu (2006) said that the more sensory organs students use in learning, the longer they keep information in memory. $91 \%$ of the students answered positively to the fifth question in the survey is consistent with the literature. Prepared audio-visual materials addressing both the vision and hearing sense of the student. Therefore, it is thought that showing both visual and audio materials together will be beneficial for students' knowledge acquisition.

All students responded positively to the sixth question in the survey shows that they liked the study and also they think that it is watched construction activities other than stone walls by preparing audio-visual materials would be beneficial. This finding is consistent with the fact that the traditional methods used in the education system are not sufficient for the students to learn the application about construction site (Koç \& Birinci 2016; Sampaio et al., 2010). Here it is seen that students need various materials to see practical information and the use of audiovisual material is thought to be a suitable material for demonstrating construction field applications to civil engineering students.

$96 \%$ of the students responded positively answer to the seventh question in the survey shows that prepared audio-visual materials are successful in teaching the construction phases of stone wall construction to the students. $90 \%$ of the students responded positively to the eighth question in the survey shows that the audio-visual materials were prepared successful in teaching the materials and technology used in stone retaining wall construction. Furthermore, 
in the light of the information presented in the answers to the 7th and 8th questions of the survey, it proves that the prepared material is liked by almost all students and it is instructive.

The answers of the students to each statement and the mean of the answers according to the likert type are given in Table 4

Table 4. Students' Opinions to Each Statement

\begin{tabular}{lllllll} 
& \multicolumn{5}{c}{ Students' Opinions } \\
Statements & LT-1 & LT-2 & LT-3 & LT-4 & LT-5 & M \\
\hline Statement 1 & & 6 & 9 & 119 & 127 & $\mathbf{4 . 4}$ \\
Statement 2 & & 2 & 4 & 106 & 149 & $\mathbf{4 . 5}$ \\
Statement 3 & 3 & 13 & 40 & 110 & 95 & $\mathbf{4 . 1}$ \\
Statement 4 & 1 & 9 & 15 & 171 & 65 & $\mathbf{4 . 1}$ \\
Statement 5 & & 1 & 20 & 132 & 108 & $\mathbf{4 . 3}$ \\
Statement 6 & & & & 68 & 193 & $\mathbf{4 . 7}$ \\
Statement 7 & & 1 & 8 & 163 & 89 & $\mathbf{4 . 3}$ \\
Statement 8 & & 5 & 21 & 170 & 65 & $\mathbf{4 . 1}$ \\
\hline
\end{tabular}

The last question was about time and analysis of students' answers are presented table 5 (LT-5 too long, LT-4 long, LT-3 appropriate, LT-2 short, LT-1 too short).

Table 5. Analysis of students' answer about time of AVM

9) Did you find the duration of the videos appropriate?

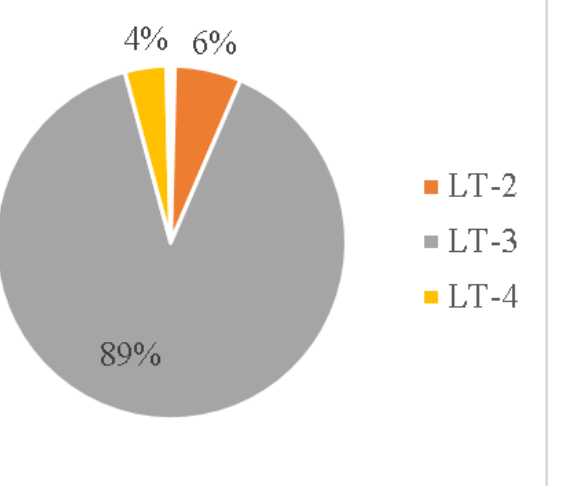

The fact that $89 \%$ of the students approved the duration of the prepared materials shows the videos are not boring, it can transfer the information without creating distraction, and the prepared material is long enough to transfer the production technology information of the related building system.

\section{CONCLUSIONS AND RECOMMENDATIONS}

In this study, whether the use of audio-visual materials in the field of construction technology contributes to traditional education is investigated by presenting an audio-visual material of real construction environment. In the preparation of the related material, attention was paid to the factors such as scientific approach, visual quality, narrative length by differing from existing similar materials. Presentation to students and survey results show that audio-visual materials can provide students the practical knowledge and field experience of building retaining walls that cannot be obtained individually in a short amount of time. The elements such as recording and editing in the study are usually prepared without professional support with standard 
equipment. Support in this direction can provide an improvement in the quality of materials. Drone can be show more clearly in every features of the construction work.

\section{REFERENCES}

Ajumobi, A. B., Malakouti, M., Bullen, A., Ahaneku, H. and Lunsford, T. N. (2016). YouTubeTM as a source of instructional videos on bowel preparation: A content analysis. Journal of Cancer Education, 31(4), 755759.

Avcıoğlu, M., 2011. Yapı teknolojisi-1 book. Birsen Yayınevi.

Belkina, M., Kelley, B. and George, L. (2015, December). Effects of video tutorials on first year engineering student's engagement and learning performance. 26th Annual Conference of the Australasian Association for Engineering Education, Australia, 344-352.

Bétrancourt, M. and Benetos, K. (2018). Why and when does instructional video facilitate learning? A commentary to the special issue "Developments and trends in learning with instructional video". Computers in Human Behavior, 89, 471-475.

Bikçe, M., Deliktaş, B., Coşkun, H. and Türker, H.T. (2011). AB Cemlib Projesi ile mühendislik mekaniği ders uygulamaları. İnşaat Mühendisliği Eğitimi 2. Sempozyumu, Muğla, Turkey, 141-148.

Boz, E., Tekin, D. and Toğan, V. (2017, May). Educational attainments of civil engineering students from their internships. 2nd International Conference on Civil and Environmental Engineering, Nevşehir, 208-214.

Brecht, H. and Ogilby, S., (2008). Enabling a comprehensive teaching strategy: Video lectures. Journal of Information Technology Education: Innovations in Practice, 7(1), 71-86.

Chakrabarti, S. K. (2016). Industry interface in undergraduate civil engineering education: Indian context. Procedia Engineering, 161, 1982-1986.

Craig and Friehs (2013). Video and HTML testing online tutorial formats with biology students. Journal of Web Librarianship, 7(3), 292-304. https://doi.org/10.1080/19322909.2013.815112

DSI (2014). Sanat Yapıları Uygulama Projeleri Yapım İşi Teknik Şartnamesi.

Fischer, J., Geurts, J., Valderrabano, V. and Hügle, T. (2013). Educational quality of Youtube videos on knee arthrocentesis. Journal of Clinical Rheumatology, 19(7), 373-376.

Hoyer, H., Jochheim, A., Rohrig, C. and Bischoff, A. (2004). A multiuser virtual- reality environment for a teleoperated laboratory. IEEE Transactions on Education, 47(1), 121-126.

Kay, R. H. (2012). Exploring the use of video podcasts in education: A comprehensive review of the literature. Computers in Human Behavior, 28(3), 820-831.

KGM (2013). Karayolu Teknik Şartnamesi (Yol Altyapısı, Sanat Yapıları, Köprü ve Tüneller, Üstyapı ve Çeşitli İşler).

Koç, V. and Birinci, F. (2016, January). Inşaat mühendisliği ĕgitiminde içselleştirilmiş bilgi kazandırmaya yönelik yapılabilecekler. 3rd Civil Engineering Education Symposium, Ankara, 65-73.

Lai, G., Zhu, Z., Tanner, J. and Williams, D. (2016, March). The effects of video tutorials as a supplement in enhancing students' statistics performance. Society for Information Technology and Teacher Education International Conference, Georgia, 1092-1099.

Lu, J. and Xue, X. (2017). Training mode of innovative talents of civil engineering education based on TRIZ Theory in China. Eurasia Journal of Mathematics, Science and Technology Education, 13(7), 4301-4309.

Martin, P. A. (2016). Tutorial video use by senior undergraduate electrical engineering students. Australasian Journal of Engineering Education, 21(1), 39-47.

Mills, J. E. and Treagust, D. F. (2003). Engineering education is problem based or project based learning the answer. Australasian Journal of Engineering Education, 3(2), 2-16.

Oğuz, C., Altın, S., Yaman, İ. Ö., Kırçıl, M. S., Bakır, A. and Sönmez, G. (2009, November). Inşaat mühendisliği ĕgitiminde Türkiye gerçeği. 1st Civil Engineering Education Symposium, Antalya, Turkey, 207-241. 
Önal, O. (2018, 25 March). Dayanma istinat yapılar (İMO-MİEK Geotechnical Course Program). http://www.imo.org.tr/resimler/dosya_ekler/0bdd5172d386727_ek.pdf.

Özkan, İ. (2011, September). Inşaat sektörünün inşaat mühendisliğine bakışı ve beklentileri. 2nd Civil Engineering Education Symposium, Mugla, Turkey, 275-286.

Prince, M. J. and Felder, R. M. (2006). Inductive teaching and learning methods: Definitions, comparisons, and research bases. Journal of. Engineering Education, 95(2), 123-138.

Raikos, A. and Waidyasekara, P. (2014). How useful is YouTube in learning heart anatomy. Anatomical Sciences Education, 7, 12-18.

Rittberg, R., Dissanayake, T. and Katz, S. J. (2016). A qualitative analysis of methotrexate self-injection education videos on YouTube. Clinical Rheumatology, 35(5), 1329-1333.

Sampaio, A. Z., Henriques, P. G. and Martins, O. P. (2010). Virtual reality technology used in civil engineering education. Open Virtual Reality Journal, 2, 18-25.

Seferoğlu, S. (2006). Öğretim teknolojileri ve materyal tasarımı. Pegem Yayıncılık.

Stefanova, T. A. (2014). Using of training video films in the engineering education. Procedia - Social and Behavioral Sciences, 116, 1181-1186.

Vergara, D., Rubio, M. P. and Lorenzo, M. (2016). New approach for the teaching of concrete compression tests in large groups of engineering students. Journal of Professional Issues in Engineering Education and Practice, 143(2), 05016009.

Vítková, E., Korytárová, J. and Hromádka, V. (2013). Support work experience of students in civil engineering. Procedia - Social and Behavioral Sciences, 93, 1940-1944.

Wang, W. F., Chen, C. M. ve Wu, C. H. (2015, July). Effects of different video lecture types on sustained attention, emotion, cognitive load and learning performance. IIAI 4th International Congress on Advanced Applied Informatics, Okayama, 385-390.

Wiggins, G. and McTighe, J. (2008). Understanding by design (2nd Edition). TESOL Quarterly, 42(1), 162-165.

Yaylacı, S., Serinken, M., Eken, C., Karcığlu, Ö., Yılmaz, A., H., E. and Dal, O. (2014). Are YouTube videos accurate and reliable on basic life support and cardiopulmonary resuscitation? Emergency Medicine Australasia, 26(5), 474- 477.

Yıldırım, N. and Özmen, B. (2011). Video paylaşım sitelerinin eğitsel amaçlı kullanımı. E Journal of New World Sciences Academy, 7(1), 288-295.

Yıldız, D. and Uzunsakal, E. (2018). Alan araştırmalarında güvenilirlik testlerinin karşılaştırılması ve tarımsal veriler üzerine bir uygulama. Applied Social Sciences Journal of Istanbul University-Cerrahpasa, 1, 115.

Zhang, D., Zhou, L., Briggs, R. O. and Nunamaker, J. F. (2006). Instructional video in e-learning: Assessing the impact of interactive video on learning effectiveness. Information \& Management, 43(1), 15-27.

a Creative Commons Attribution-NonCommercial-ShareAlike 4.0 International License. 